\title{
Migrants Feared and Forsaken: A Catholic Ethic of Social Responsibility
}

\author{
Kristin E. Heyer \\ Theology Department, Boston College, Boston, MA, USA \\ heyerkr@bc.edu
}

\begin{abstract}
Basic human rights reflected in international rights regimes and presupposed in Catholic social ethics are universal in theory, yet in practice their exercise depends upon legally sanctioned membership in a political community. This gap between the normativity of the dignity of the migrant and the practical denial of their rights is maintained by (1) standard paradigms for analysing migration and (2) a related neglect of structural injustices that facilitate rights violations. The Catholic tradition's social anthropology, understanding of social sin, and commitment to a global common good are poised to reorient responsibility for irregular migration beyond individuals who cross borders or overstay visas alone.
\end{abstract}

\section{Keywords}

global common good - migration - social responsibility - structural sin

Recent years have witnessed a rise in nativist populism fuelled, in part, by anxieties about the economic and cultural impact of globalization. ${ }^{1}$ Politicians running on populist platforms have capitalized on peoples' fears of demographic shifts and chaotic border scenes, asserting that they alone are willing to control borders and restore law and order. Across different European countries

1 Portions of this essay draw upon arguments elaborated further in Heyer, Internalized Borders, p. 146-164 and Heyer, Kinship Across Borders. 
nationalist parties have capitalized on settled populations' discomfort with new migrant flows, socio-economic precarity and fear of terrorism. ${ }^{2}$ Brazil's recently elected Jair Bolsonaro has withdrawn the country from the compact on migration. ${ }^{3}$ In the US context, similar trends have played out via Donald Trump's politics and policies of exclusion, where appeals to economic and cultural anxieties remain cloaked in nativist rhetoric and misrepresentations of immigrant threats.

Patterns that instill fear in receiving communities and erode the human rights of migrants reflect tendencies to approach migration in terms of crisis management. Yet understanding immigration in terms of the discrete actions of emigrants, wherein individuals are the primary site for enforcement and responsibility, disregards histories of relationship between sending and receiving countries and transnational politics and economies. Historian Mae Ngai has characterized persons on the move as impossible subjects, arguing they are legal and political subjects without rights, persons who cannot be, and problems that cannot be solved, produced by immigration restrictions. ${ }^{4}$ For whereas the basic human rights reflected in international rights regimes (and presupposed in Catholic social thought) are universal in theory, in practice their exercise depends upon legally sanctioned membership in a political community. ${ }^{5}$ Christian understandings of what it means to be human radically critique the pervasive exploitation of migrants, whether via wage theft, sexual assault, deaths in detention facilities, or protracted family separation. An anthropology rooted in the imago Dei underscores the (Trinitarian) sociality of persons, not only their inherent dignity independent of citizenship status; these intrinsically relational elements help illuminate complex causes of migration and the responsibilities of receiving communities. This essay explores how the gap between the normativity of the dignity of the migrant and the practical denial of their rights is maintained by (1) standard paradigms for analysing migration and (2) a related neglect of structural injustices that facilitate rights violations. The Catholic tradition's social anthropology, understanding of social sin, and commitment to a global common good are poised to reorient responsibility for irregular migration beyond individuals who cross borders or overstay visas alone.

2 Heimbach-Steins, New Nationalisms in Europe.

3 Clarke, While U.S. Fixates on the Border Wall.

4 Ngai, Impossible Subjects, p. 4 et seq.

5 O'Neill, Rights of Passage, p. 113-136. 


\section{Migration Ethics: Standard Cosmopolitan and Communitarian Frameworks}

Literature in migration ethics typically focuses upon the plight and agency of migrants and relative duties of reception within a shifting, globalized framework. Standard communitarian and cosmopolitan models tend to primarily focus upon rights to freedom of movement and political communities' selfdetermination, but secular and theological versions of these dominant approaches fall short of providing meaningful protections for the persons on the move, Ngai's impossible subjects. For example, a global rights regime reflecting a liberal respect for the generalized other largely fails to generate substantive obligations of provision for migrants or to protect would-be migrants from systemic deprivation. On more communitarian models, undocumented migrants are at best owed forbearance, lacking legal claim to the "good of citizenship and its attendant claim-rights". ${ }^{6}$ Even in an increasingly globalized society, enjoying or enforcing positive claim rights remains bound to citizenship, so that the loss of home and political status is tantamount to "expulsion from humanity altogether".

Generally speaking, classical liberals urge more open borders than migrants now enjoy on the grounds of the moral weight of freedom of movement whereas social liberals appeal to values of equality and justice to ground migrants' welfare. ${ }^{8}$ For those who subscribe to cosmopolitan approaches, national boundaries require moral justification. ${ }^{9}$ Kwame Anthony Appiah's rooted cosmopolitanism attempts to affirm common humanity without effacing concrete cultural, religious and gender particularities or rootedness in communities. ${ }^{10}$

6 O'Neill, Rights of Passage, p. 115 et seq. Claim rights entail substantive responsibilities on the part of other parties toward the right-holder beyond immunities from intrusion or coercion.

O'Neill, Rights of Passage, p. 116. He cites Arendt, The Perplexities of the Rights of Man, p. 88.

8 Abizadeh, Closed Borders, p. 150-153. See also Seglow, The Ethics of Immigration, p. 319. As Benhabib notes, for some this more universalist perspective signifies an enlightened moral attitude that does not elevate "love of country" above love of humankind (see Nussbaum, Patriotism and Cosmopolitanism, p. 2-20 [Original in Boston Review October/ November 1994]). For others, she notes, "cosmopolitanism signifies hybridity, fluidity, and recognizing the fractured and internally riven character of human selves and citizens, whose complex aspirations cannot be circumscribed by national fantasies and primordial communities" (See Waldron, Minority Cultures and the Cosmopolitical Alternative, p. 19). Benhabib advances cosmopolitan norms that frame the morality of law in a global context, governing relations among individuals in a global civil society. Benhabib, Another Cosmopolitanism, p. 20. 
Differences are celebrated on this model as long as basic human rights are respected. These appeals to a globalization of citizenship - claiming membership in the world community and obtaining rights that derive primarily from one's humanity as such and only secondarily as members of existing nation states - hold promise for transnational migration by considering human rights independent of community membership, but fall short absent adequate enforcement mechanisms in the present nation-state configuration or an effectively operative global authority.

Beginning from a more narrowly circumscribed understanding of belonging, communitarian arguments regarding border control root defense of membership restrictions in the duties of states to preserve particular cultures or political identities. Michael Walzer's proposal that "the very idea of distributive justice presupposes a bounded world" of members and outsiders, such that membership in such a (political) community is the "primary good that we distribute to one another" continues to hold relevance. ${ }^{11}$ This framework does not provide migrants with any claim for admission in justice. ${ }^{12}$ Walzer's argument for communitarian justice elevates the value of democratic sovereignty over that of global justice; given the historical values, traditions and practices that mark political societies, "admission and exclusion are at the core of communal independence."13 Hence on this view justice resides chiefly within and not between states due to the overriding values of a cultural community identified with the nation state. ${ }^{14}$ Related to this set of rationales is a democratic association argument, which appeals to values of democracy, sovereignty and self-determination, elevating an interest in democratic deliberation such that citizens should have the freedom to decide on matters of common concern, such as admissions restrictions, with their co-citizens. ${ }^{15}$

Critics have pointed out the ways in which any one model falls short of meaningful protections and provisions for the "stateless". ${ }^{16}$ William O'Neill asserts that in communitarianism, undocumented migrants are at best owed forbearance, lacking "legal title to the primary good of citizenship and its

\footnotetext{
11 Walzer, Spheres of Justice, p. 31.

12 Seglow, The Ethics of Immigration, p. 320. Walzer concedes a principle of "mutual aid" in cases where strangers "have no other place to go", but he claims citizens have no formal obligations in this regard. See Walzer, Spheres of Justice, p. 45 et seq.

13 See Walzer, Spheres of Justice, p. 62.

14 Seglow, Ethics of Immigration, p. 321.

15 Seglow, Ethics of Immigration, p. 330.

16 For a critique of liberal egalitarian arguments for open and closed borders, see Abizadeh, Closed Borders, p. 147-168.
} 
attendant claim-rights" ${ }^{17}$ For he notes that "even with the partial eclipse of the Westphalian nation-state system", enjoying or enforcing positive claim rights remains bound to citizenship, so that the loss of home and political status is tantamount to "expulsion from humanity altogether". 18 On the other hand, he suggests that a global rights regime likewise restricts migrants' claims, for liberal respect for the generalized other largely fails to generate substantive obligations of provision for migrants or to protect would-be migrants from the systemic deprivation outlined above. ${ }^{19}$

O'Neill forwards a via media between these dominant approaches rooted in a rights-based conception of the common good. He argues that Catholic social thought's generalized respect for the concrete other - envisioned as "solidarity with near and distant neighbors" - mediates between the communitarian recognition of concrete members and strangers and liberalism's respect for "abstract citizens". ${ }^{20}$ More broadly, "[r]ecognition of the 'stranger' or 'alien' as neighbor - and thus as a juridical person and claimant - attests to our common 'faith in fundamental human rights, in the dignity and worth of the human person,' a faith underwritten by, even as it is expressed within, our different comprehensive religious traditions."21 The range of human rights grounded in human dignity in the tradition encompasses civil-political, socioeconomic and cultural rights, guaranteeing freedom for participating in the life of the community. In terms of political arrangements that safeguard such rights for the most vulnerable, a Catholic understanding of the state ordered to safeguard basic human rights and promote the common good transcends border- or culture-specific claims. For migrants unable to meet their basic needs in their origin countries, the protection of basic rights related to family and work, for example, cannot in practice be realized without a viable path to citizenship. ${ }^{22}$

17 O'Neill, Rights of Passage, p. 115 et seq. Claim rights entail substantive responsibilities on the part of other parties toward the right-holder beyond immunities from intrusion or coercion.

18 O'Neill, Rights of Passage, p. 116. He cites Arendt, The Perplexities of the Rights of Man, p. 88.

19 O'Neill, Anamnestic Solidarity.

20 O'Neill, Anamnestic Solidarity, p. 123. O'Neill alludes to the call in Gaudium et Spes to "make ourselves the neighbor of every person without exception." Second Vatican Council, Gaudium et Spes, no. 27.

21 O'Neill, Anamnestic Solidarity, p. 123. O'Neill quotes here the Universal Declaration of Human Rights, p. 310.

22 Kerwin, Toward a Catholic Vision of Nationality, p. 203. "The Church charges the state with the duty of reception to immigrants if consistent with the common good." See John XXIII, Pacem in Terris, no. 106. 

Responsibilities

This attention to the Catholic tradition of the common good helps bridge the gap between rights and concrete responsibilities as well as contextualize sovereignty claims. For whereas the tradition recognizes the right of sovereign nations to control their borders, the right is not understood to be absolute; in the case of blatant human rights violations, the right to state sovereignty is relativized by the tradition's primary commitment to protecting human dignity. Human rights violations can supersede the right to control borders, as "states exist to vindicate rights, but they do not create them." ${ }^{23}$ For in contrast to a Hobbesian notion that sovereignty defines legitimacy, institutional arrangements, including citizenship in a particular polity, are legitimate only if they subserve the global common good, our moral citizenship in a world community. Yet it is just this cosmopolitan citizenship that is mediated in, and across our concrete, particular polities, so that the victims of forced migration, even if undocumented, are never rhetorically effaced, never "rightless". ${ }^{24}$ Patterns wherein stable receiving countries accept the labour of undocumented workers without offering legal protections of citizenship risk the creation of a permanent underclass, leading to both exploitation of laborers and a two-tiered society, which harms human dignity and the common good alike. Hence, an understanding of solidarity with near and distant strangers can help move beyond the liberal-communitarian impasse and orient considerations of migrants' rights in terms of broader relationships abetting forced movement.

Emphasizing the demands of the global common good underscores the social dimensions of justice and complicity alike. If dominant political narratives keep violence and migration flows local and de-humanize newcomers according to convenient scripts, the Christian tradition's social commitments shape a different story, a counternarrative of shared humanity with implications for a justice-oriented immigration ethic. Drawing on traditions of biblical hospitality, human rights, and its social doctrine, a Catholic migration ethic is not a meek, naïve paradigm that simply condones open borders, but rather it demands shared responsibility for the effects of structural injustice. The tradition's defense of social, economic and cultural rights is rooted in a social anthropology that departs from the atomistic monad or homo economicus implicit in some approaches to migration policy. An anthropology that joins autonomy and relationality contests both the dehumanizing manipulation and

23 Kerwin, Rights, the Common Good, p. 95.

24 O'Neill, Rights of Passage, p. 123. 
exploitation of migrants as well as the inadequacy of individualistic frameworks in migration ethics.

Relational emphases help us consider the roles historical relationships and transnational actors play in abetting migration. Typically established communities and migrants are "bound together by history, politics and economics even before the act of migration bridges the distance of geography." 25 Dynamics of employer recruitment tend to be shaped by prior bonds impacted by colonialism, military invasions, or economic ties: the ongoing legacy of nineteenth- and twentieth-century US foreign policy, expansionism and neoliberal economic strategies - with attendant narratives - has generated migration flows from Latin America to the United States, for example. ${ }^{26}$ Understanding immigration dynamics as related to unjust international political and economic divides also requires nations to share accountability in the wake of the Westphalian model's partial eclipse and to convert from opportunistic patterns of interdependence. More structural analyses suggest that migration policy should consider receiving countries' economic and political complicity in generating migrant flows rather than perpetuate amnesic scapegoating. Saskia Sassen links deeper dynamics of debt servicing and extraction to new migratory flows, illuminating their complex origins given predatory forms of advanced capitalism, opaque transnational networks, and a global governance system geared to aiding corporations. ${ }^{27}$

Given such systemic culpability, some have proposed an instability tax be levied upon private and governmental entities that destabilize migrant- and refugee-producing regions - whether hedge funds profiting off of commoditytrading in African minerals or weapons manufacturers profiting from selling arms to the Middle East, or multinationals who profit from degrading or destabilizing poor nations. ${ }^{28}$ Drawing on the Kew Gardens principles, David Hollenbach has proposed norms that help account for histories of relationship and complicity. In light of moral proximity to harm, he suggests countries that have gained economically from their colonies or with histories of military involvement in another nation "have special obligations to people in flight from that nation". ${ }^{29}$ Existing economic relationships also confer relative duties, such that guest workers who "contribute through their work to the

25 Allard, Who Am I?, p. 325.

26 De La Torre, The U.S. Immigration Crisis, p. 151 et seq. He reflects on a personal level: "I am in this country following my sugar, tobacco and rum" (p. 158).

27 Sassen, Three Emergent Migrations, p. 211.

28 Almond, The Migrant Crisis.

29 Hollenbach, Borders and Duties to the Displaced, p. 153. 
life and well-being of the society they have entered" should be welcomed as citizens. ${ }^{30}$

Hence becoming neighbour to the migrant on a social vision of the person and shared vision of the good demands meeting basic responsibilities in justice, not charity alone, particularly given the role receiving nations play in shaping conditions that directly contribute to irregular migration. ${ }^{31}$ Hence whereas standard models tend to primarily focus upon rights to freedom of movement and political communities' self-determination, categories like restorative justice and the global common good contextualize the individual acts of migrants and underscore social dimensions of justice. A social anthropology with its attendant rights and robust vision of responsibilities helps enlarge analyses of migration in the face of tendencies to locate responsibility solely with a migrant's choice to cross borders, absent attention to transnational forces and contexts.

Social Sin: Structural and Ideological Impediments to Migrants' Rights

The Christian category of social sin explicitly connects these structural relationships with their harmful consequences and abetting ideologies. The multilayered dynamics of social sin also account for the gap between the normativity of human dignity and the widespread violation of migrants' rights. Distinct elements of social sin - dehumanizing trends, unjust structures and harmful attitudes - shape complex dynamics that perpetuate inequalities and influence receptivity to outsiders. ${ }^{32}$ These elements illuminate the connections between harmful structures and ideologies: for example, ways in which powerful narratives casting immigrants as security threats or takers influence individuals' roles in collective actions that impact migration, such as votes in an election. Given the nonvoluntary dimensions of social sin, a Catholic social ethic calls for not only defending human rights or providing hospitality to strangers, but also unmasking the complex structures and ideologies that abet personal complicity, preventing justice for migrants. Intertwined patterns of social sin require repentance from idolatries that marginalize and disempower those beyond one's immediate sphere of concern. From repentance and

$30 \quad$ Hollenbach, A Future Beyond Borders, p. 232.

31 Hoeffner/Pistone, But the Laborers, p. 74.

32 For an in-depth discussion of the evolution of the category of social sin and its application to immigration ethics, see Heyer, Good Fences Make Bad Neighbors. 
conscientization a relational ethic invites conversion toward interdependence in solidarity, both at a personal level, evoking new perspectives and receptivity, as well as at a broader systemic level, with nations taking more collective responsibility. Converting patterns of global interdependence from ones marked by domination and oppression to ones marked by equality and reciprocity demands structures of institutional accountability with teeth as well as empowered participation (subsidiarity). ${ }^{33}$

Hence beyond identifying structural forces demanding institutional solidarity, Catholic migration ethics entails interrogating more ideological dimensions of social sin that harden resistance to newcomers. Pope Francis has drawn attention to anesthetizing effects of indifference in this regard, calling for a re-cognition of our fundamental relatedness in light of the harm borders wreak. On Lampedusa he lamented the pervasive idolatry that facilitates migrants' deaths and robs us of the ability to weep, a theme he revisited in Manila and then Juárez, insisting "only eyes cleansed by tears can see clearly."34 The reductive market ethos dominating trade and migration policies has similarly desensitizing effects. Pope Francis connects this logic of exclusion based on materialism to perceptions and treatment of migrants as disposable. ${ }^{35}$ Migrant women's often exploitative caring labour that sustains citizens' wage labour offers one example. The idea that the economy should serve the person raises serious concerns not only about the freedom of markets compared to people, but also about the significant financial stakes in broken immigration systems detained immigrants fill beds, deportations fill private buses. Social sin, then, connects a framework able to critique histories of unequal relationships between countries, such as histories of proxy wars, with one able to surface and identify harmful ideologies, from xenophobia to meritocracy. Marianne Heimbach-Steins has noted how colonial structures shaped not only long-term international political and economic relationships that have inhibited equal participation, but also culturalist patterns and ideologies of domination that continue to influence migration barriers and power asymmetries. ${ }^{36}$ Idolatries of security and invulnerability also facilitate susceptibility to exclusionary temptations. Portraying immigration through a lens of individual culpability alone obscures these multileveled dynamics at play. Hence categories of social sin and transnational solidarity orient migration analyses toward root causes

33 Hollenbach, Common Good \& Christian Ethics, p. 225.

34 Francis, No Border Can Stop Us.

35 Guerra, A Church without Boundaries, p. 51.

36 Heimbach-Steins, Migration in a Post-colonial World, p. 87, p. 93. 
of displacement and shared accountability that can help close the gap between affirmations of human dignity and pervasive migrant rights violations.

Certainly, the unprecedented number of migrants crossing borders today issues complex challenges to communities of origin and reception alike, and reasonable restrictions and modernized protocols are warranted. Migrant deaths in the Mediterranean and Arizona desert alike make poignantly clear the stakes of nations failing to understand themselves as collectively responsible for these shared challenges, however. Expedient political rhetoric masks wider complicity and abets human rights violations, and yet dominant theoretical paradigms that focus on symptoms of migration alone similarly fail to bridge the distance between rights claims and concrete protections. Given how isolation from immigrants' realities allows citizens to commodify, politicize, scapegoat, or ignore them, a Catholic emphasis on the social dimension of the person, of sin, and of responsibility can refocus attention on broader contexts of injustice and shared accountability.

\section{Biography}

Kristin E. Heyer is professor of theological ethics and director of graduate studies in the theology department at Boston College. She also serves as cochair of Catholic Theological Ethics in the World Church. She received her B.A. from Brown University and her Ph.D. in theological ethics from Boston College in 2003. Her books include Kinship Across Borders: A Christian Ethic of Immigration (2012) and Prophetic and Public: The Social Witness of U.S. Catholicism (2006), which won the College Theology Society's "Best Book Award", both published with Georgetown University Press. She has also published four co-edited volumes: Building Bridges in Sarajevo: The Plenary Papers from CTEWC 2018 (Orbis Press, 2019); Public Theology and the Global Common Good: The Contribution of David Hollenbach (Orbis Press, 2016); Conscience and Catholicism: Rights, Responsibilities and Institutional Responses (Orbis Press, 2015) and Catholics and Politics: Dynamic Tensions between Faith and Power (Georgetown University Press, 2008).

\section{Bibliography}

Abizadeh, Arash: "Closed Borders, Human Rights, and Democratic Legitimation", in: David Hollenbach (ed.): Driven from Home. Protecting the Rights of Forced Migrants. Washington, DC: Georgetown University Press, 2010, p. 147-168. 
Allard, Silas W.: "Who Am I? Who Are You? Who are We? Law, Religion, and Approaches to an Ethic of Migration", in:Journal of Law and Religion 30 (2015), p. 320-334.

Almond, Ian: “The Migrant Crisis. Time for an Instability Tax?", in: Political Theology Today, 22.09.2015, http://www.politicaltheology.com/blog/the-migrant-crisis-timefor-an-instability-tax/ (date of last access: 11.03.2020).

Appiah, Kwame Anthony: "Cosmopolitan Patriots", in: Joshua Cohen/Martha Nussbaum (ed.): For Love of Country, Boston, MA: Beacon Press 2002, p. 21-29.

Arash, Abizadeh: "Closed Borders, Human Rights, and Democratic Legitimation", in: Driven from Home. Protecting the Rights of Forced Migrants. Washington, DC: Georgetown University Press, p. 147-168.

Arendt, Hannah: "The Perplexities of the Rights of Man”, in: Headline Series 318 (Winter/1998), p. 88.

Benhabib, Seyla: Another Cosmopolitanism. Edited and introduced by Robert Post. New York, NY: Oxford University Press, 2008.

Castillo Guerra, Jorge E.: “A Church without Boundaries'. A New Ecclesial Identity Emerging from a Mission of Welcome. Reflections on the Social Magisterium of Pope Francis as related to Migration", in:Journal of Catholic Social Thought 14 (2017), p. $43^{-61 .}$

Clarke, Kevin: "While U.S. fixates on the border wall, populist world leaders still turn migrants away", in: America, 11.01.2019, https://www.americamagazine.org/politicssociety/2019/o1/11/while-us-fixates-border-wall-populist-world-leaders-still-turnmigrants (date of last access: 11.03.2020).

De La Torre, Miguel: The U.S. Immigration Crisis. Toward an Ethics of Place. Eugene, OR: Cascade, 2016.

Francis [Pope]: "No Border Can Stop Us from Being One Family", 18.02.2016, http:// paulinesafrica.org/pope-francis-no-border-can-stop-us-from-being-one-family/ (date of last access: 11.03.2020).

Heimbach-Steins, Marianne: "Migration in a Post-colonial World", in: Gemma Tulud Cruz (ed.): Religious and Ethical Perspectives on Migration, Lanham, MD: Lexington, 2014, p. 87-107.

Heimbach-Steins, Marianne: "New Nationalisms in Europe and the Ambivalent Role of Religion", in: The First. Catholic Theological Ethics in the World Church, 31.03.2016, http://www.catholicethics.com/forum-submissions/new-nationalisms-in-europeand-the-ambivalent-role-of-religion (date of last access: 11.03.2020).

Heyer, Kristin: "Internalized Borders. Immigration Ethics in the Age of Trump", in: Theological Studies 79 (1/2018), p. 146-164.

Heyer, Kristin: Kinship Across Borders. A Christian Ethic of Immigration. Washington, D.C.: Georgetown University Press, 2012.

Heyer, Kristin: "Social Sin and Immigration. Good Fences make Bad Neighbors", in: Theological Studies 71 (2/2010), p. 410-436. 
Hoeffner, John J./Pistone, Michele R.: "But the Laborers Are Many? Catholic Social Teaching on Business, Labor and Economic Migration”, in: Donald Kerwin/Jill Marie Gerschutz (ed.): And You Welcomed Me. Migration and Catholic Social Teaching. Lanham, MD: Lexington Books, 2009, p. 55-92.

Hollenbach, David: "A Future Beyond Borders. Re-imagining the Nation State and the Church", in: Agnes Brazal/María Teresa Dávila (ed.): Living With(out) Borders. Catholic Theological Ethics on the Migrations of Peoples. Maryknoll, NY: Orbis Press, 2016, p. 223-235.

Hollenbach, David: "Borders and Duties to the Displaced. Ethical Perspectives on the Refugee Protection System", in: Journal on Migration and Human Security 4 (2016), p. 148-165. https://doi.org/10.14240/jmhs.v4i3.66 (date of last access: 11.03.2020).

Hollenbach, David: Common Good \& Christian Ethics. Cambridge: Cambridge University Press, 2002.

John XXIII: "Pacem in Terris. Encyclical of Pope John XXIII on Establishing Universal Peace in Truth, Justice, Charity, and Liberty", 11.04.1963, http://www.vatican.va/ content/john-xxiii/en/encyclicals/documents/hf_j-xxiii_enc_11041963_pacem.html (date of last access: 22.04.2020).

Kerwin, Donald: "Rights, the Common Good, and Sovereignty in Service of the Human Person", in: Donald Kerwin/Jill Marie Gerschutz (ed.): And You Welcomed Me. Migration and Catholic Social Teaching. Lanham, MD: Lexington Books, 2009, p. 93-122.

Kerwin, Donald: "Toward a Catholic Vision of Nationality", in: Notre Dame Journal of Law, Ethics \& Public Policy 23 (2009), p. 197-207.

Ngai, Mae M.: Impossible Subjects. Illegal Aliens and the Making of Modern America. Princeton, NJ: Princeton University Press, 2004.

Nussbaum, Martha: "Patriotism and Cosmopolitanism", in: Joshua Cohen (ed.): For Love of Country. Debating Patriotism and its Limits. Boston, MA: Beacon Press, 1996, p. 2-2O.

O’Neill, William R.: "Anamnestic Solidarity. Immigration from the Perspective of Restorative Justice", paper delivered at the 2009 Catholic Theological Society of America (Halifax, Nova Scotia), 05.06.2009.

O'Neill, William R.: "Rights of Passage. Ethics of Forced Displacement”, in: The Journal of the Society of Christian Ethics 27 (1/2007), p. 113-136.

Sassen, Saskia: "Three Emergent Migrations. An Epochal Change", in: SUR File on Migration and Human Rights 13 (2016), p. 29-41.

Sassen, Saskia: “A Massive Loss of Habitat. New Drivers for Migration”, in: Sociology of Development 2 (2/2016), p. 204-223. https://doi.org/10.1525/sod.2016.2.2.204 (date of last access: 11.03.2020).

Seglow, Jonathan: "The Ethics of Immigration”, in: Political Studies Review 3 (3/2005), p. 317-334. 
Waldron, Jeremy: "Minority Cultures and the Cosmopolitical Alternative", in: Will Kymlicka (ed.): The Rights of Minority Cultures. Oxford: Oxford University Press, 1995.

Walzer, Michael: Spheres of Justice. A Defense of Pluralism and Equality. New York, NY: Basic Books, 1983. 